\title{
A Three-Year Study of Enterohemorrhagic Escherichia coli 0157 on a Farm in Japan
}

\author{
Ayako EZAWA ${ }^{1)}$, Fumie GOCHO $^{1)}$, Miyuki SAITOH ${ }^{1)}$, Toshiki TAMURA ${ }^{1)}$, Koji KAWATA ${ }^{1)}$, \\ Tatsuhumi TAKAHASHI ${ }^{1)}$ and Naoya KIKUCHI ${ }^{1) *}$ \\ ${ }^{1)}$ Department of Epizootiology, School of Veterinary Medicine, Rakuno Gakuen University, Ebetsu, Hokkaido 069-8501 Japan
}

(Received 26 September 2003/Accepted 10 February 2004)

ABSTRACT. A long-term study was performed on the prevalence of enterohemorrhagic Escherichia coli (EHEC) O157 in bovine faeces. The present study was conducted on heifers raised on a farm showing a high isolation rate of EHEC O157 in previous years. The p revalence of EHEC O157 isolated from faecal samples was 10.6\% (222/2104), 5.6\% (181/3225), and 5.6\% (153/2744) from 1998 to 2000, respectively. The numbers of EHEC O157-positive heifers for the same 3 years were $46.3 \%$ (185/400), 36.8\% (147/399), and 31.7\% (130/410), respectively. The seasonal prevalence of EHEC O157 varied according to the year. Most positive heifers excreted the EHEC $\mathrm{O} 157$ only once during the survey, though it was excreted 2 or 3 times by some heifers. The results obtained in the present study showed that the farm examined was heavily contaminated with EHEC O157. It is assumed that EHEC O157 does not remain in individual catt le long-term, but does exist long-term on farms due to repeated infection.

KEY WORDS: cattle, EHEC O157, environment, prevalence.

J. Vet. Med. Sci. 66(7): 779-784, 2004

Shiga toxin (Stx)-producing Escherichia coli (STEC) is an important causative agent of diarrhea, hemorrhagic colitis (HC), and hemolytic-ureamic syndrome (HUS) in humans. STEC strains isolated from patients are also designated enterohemorrhagic Escherichia coli (EHEC) [9, 17]. EHEC infection is a typical example of an emerging infection.

Serotypes of EHEC causing outbreaks of HC and HUS have been of certain types such as $\mathrm{O} 26, \mathrm{O} 103, \mathrm{O} 111, \mathrm{O} 128$, $\mathrm{O} 145$ and $\mathrm{O} 157$. Virulence factors of the organisms include the production of phage-encoded toxins, Stx 1 and Stx2, which are thought to cause vascular endothelial damage in patients with $\mathrm{HC}$ and HUS.

Cooked ground beef, cow milk, dairy products, and so on are thought to be the major sources of EHEC infection [4, $26,27]$, and cattle and other ruminants, such as sheep and goats, are known to harbor the organisms in their faeces and are regarded as natural reservoirs of the organisms $[2,3,5$, $22,25]$. The prevalence of EHEC O157 in cattle has been reported to be $0.2-60.4 \%$ in the United States [10, 13, 23, 28], 1.9\% in Australia [7], and 4.2-66.7\% in Europe [5, 6, $16,24]$. In Japan, it was reported that the isolation rate of the EHEC was between $0.3 \%$ [12] and 6.5\% [15] in faeces samples from animals delivered to a slaughterhouse. In a nationwide survey of EHEC O157, the organisms were isolated from $1.4 \%$ of faeces and $0.3 \%$ of dressed carcasses. Little information is available concerning the prevalence of EHEC O157 in cattle reared on farms in Japan. Kobayashi et al. [14] reported that the prevalence of EHEC was more than $60 \%$ in the faeces of cows and heifers, but 0157 was only 1 of 92 isolates. Furthermore, there is little information

\footnotetext{
* Correspondence to: Kikuchi, N., Department of Epizootiology, School of Veterinary Medicine, Rakuno Gakuen University, Ebetsu, Hokkaido, 069-8501, Japan.
}

from long-term studies on the prevalence of EHEC O157 on farms. We previously reported that a remarkably high isolation rate was found on a farm that raised heifers [8].

The aim of the present study was to analyze the epidemiological situation concerning EHEC O157 on the dairy farm by the long-term monitoring of individual cattle. In addition, we also performed a bacterial survey for EHEC O157 from various environmental samples from the farm.

\section{MATERIALS AND METHODS}

Farm: The farm, T Farm, was located in central Hokkaido, Japan and was stocked with about 400 heifers (over 12 months old) each year. In April, heifers were assembled from many neighboring dairy farms and then fed on $\mathrm{T}$ farm. The heifers were kept on pasture from April to September, and were artificially inseminated and given a medical check once a month. Those that did not fall pregnant were raised on the farm until the April of the following year in a loose barn. Most of the heifers were returned to the respective dairy farms by December.

Sampling: Rectal faeces samples were obtained once a month from each heifer between 1998 and 2000. All heifers were identified by ear tag numbers. Environmental samples (from bedding; feeding trough; wall; alley; water trough; dried faeces in paddocks; mineral blocks) were obtained between June 1999 and April 2000. To obtain samples, a $10-\mathrm{cm}$ square area at each sampling point was wiped with a swab. All samples were immediately transported to the laboratory in cooler boxes.

Isolation of EHEC O157: About $10 \mathrm{~g}$ of each faeces and environmental swab were cultured by incubation in $100 \mathrm{ml}$ of mEC broth containing novobiocin $(20 \mu \mathrm{g} / \mathrm{ml})$ at $43^{\circ} \mathrm{C}$ for 18-20 hr, followed by plating on MacConkey Sorbitol agar 
(Nissui, Tokyo, Japan) containing cefixime $(50 \mu \mathrm{g} / \mathrm{m} l)$ and potassium tellurite $(1.25 \mathrm{mg} / \mathrm{ml})$ at $37^{\circ} \mathrm{C}$ for $20-24 \mathrm{hr}$. Sorbitol non-fermenting colonies were selected and regarded as EHEC. Serotyping of isolates was carried out by agglutination test with anti-O157 and anti-H7 sera (Denka Seiken, Tokyo, Japan).

Characteristics of EHEC 0157 isolates: The stx, st $x_{1}$ and $s t x_{2}$ genes were detected by PCR. PCR for stx genes was performed by the method previously described with minor modifications [20]. EHEC O157 isolates were harvested from Trypticase Soy Agar (Becton Dickinson and Company, Sparks, U.S.A.), suspended in $100 \mu l$ of sterile water. The bacterial suspension was incubated at $95^{\circ} \mathrm{C}$ for $5 \mathrm{~min}$, and centrifuged at $12,000 \mathrm{rpm}$ for $10 \mathrm{~min}$. The supernatant was then used as template DNA. Amplifications were performed in a total volume of $50 \mu l$ containing dNTP at 200 $\mu \mathrm{M}, 0.19 \mu \mathrm{M}$ of each primer (stx; 5'-CGGACAGTAGTTATACCAC-3' and 5'-CTGCTGTCACAGTGACAAA3', st $x_{1}$; 5'-CAACACTGGATGATCTCAG-3' and 5'CCCCCTGAACTGCTAATA-3', st $x_{2} ;$; '-ATCAGTCGTCACTCACTGGT-3' and 5'-CCAGTTATCTGACATTCTG-3'), $5 \mu l$ of $10 \mathrm{X}$ Ex Taq Buffer ${ }^{\mathrm{TM}}$, and $2.5 \mathrm{U}$ of TaKaRa Ex Taq ${ }^{\mathrm{TM}}$ (TaKaRa, Shiga, Japan). PCR conditions were as follows: 30 cycles beginning with denaturation at $94^{\circ} \mathrm{C}$ for $60 \mathrm{sec}$, primer annealing at $55^{\circ} \mathrm{C}$ for $60 \mathrm{sec}$, followed by extension at $72^{\circ} \mathrm{C}$ for $60 \mathrm{sec}$. PCR products were analyzed by agarose gel electrophoresis in a 3\% Nusieve 3:1 agarose gel (BMA, Rockland, U.S.A.).

\section{RESULTS}

Isolation and prevalence of EHEC O157 from faeces of heifers: The prevalence of EHEC O157 in the faeces of heifers on the farm from 1998 to 2000 is shown in Table 1. The faecal samples were collected from heifers on the farm in Hokkaido 10, 13 and 12 times from June 1998 to April 1999 (designated 1998), April 1999 to April 2000 (designated 1999), and May 2000 to April 2001 (designated 2000), respectively. EHEC 0157 was isolated from 222 (10.6\%) of 2104 faeces samples in 1998. The isolation rate decreased thereafter, to $5.6 \%$ and $5.6 \%$ in 1999 and 2000, respectively. The average isolation rate of EHEC 0157 from bovine faeces on the farm during the 3 years was $6.9 \%$ (556/8073). About $40 \%$ of heifers examined were found positive for EHEC O157 during the bacterial survey each year. The prevalence of EHEC $\mathrm{O} 157$ by month on the farm was also analyzed (Table 2 and Fig. 1). Heifers positive for EHEC $\mathrm{O} 157$ were found throughout the 3 -year period. The highest isolation rate was observed in August 1998, in which $23.0 \%$ of the cattle were found to be EHEC 0157 positive. In 1998 and 1999, the prevalence of EHEC O157 was higher in the summer and winter than in spring, whereas

Table 1. Prevalence of EHEC O157 from the faeces of heifers on the farm in Hokkaido from 1998 to 2000

\begin{tabular}{|c|c|c|c|c|c|c|c|c|}
\hline \multirow[t]{2}{*}{ Year } & \multirow[t]{2}{*}{ Period } & \multirow{2}{*}{$\begin{array}{c}\text { Times of } \\
\text { testing }\end{array}$} & \multicolumn{3}{|c|}{ Faeces } & \multicolumn{3}{|c|}{ Heifers } \\
\hline & & & Examined & Positive & Prevalence $(\%)$ & Examined & Positive & Prevalence $(\%)$ \\
\hline 1998 & $\begin{array}{l}\text { June } 1998 \\
\text {-April } 1999\end{array}$ & 10 & 2104 & 222 & 10.6 & 400 & 185 & 46.3 \\
\hline 1999 & $\begin{array}{l}\text { April } 1999 \\
\text {-April } 2000\end{array}$ & 13 & 3225 & 181 & 5.6 & 399 & 147 & 36.8 \\
\hline 2000 & $\begin{array}{l}\text { May } 2000 \\
\text {-April } 2001\end{array}$ & 12 & 2744 & 153 & 5.6 & 410 & 130 & 31.7 \\
\hline Total & & 35 & 8073 & 556 & 6.9 & 1209 & 462 & 38.2 \\
\hline
\end{tabular}

Table 2. Prevalence of EHEC O157 from the faeces by month

\begin{tabular}{|c|c|c|c|c|c|c|c|c|c|}
\hline \multirow[b]{2}{*}{ Month } & \multicolumn{3}{|c|}{1998} & \multicolumn{3}{|c|}{1999} & \multicolumn{3}{|c|}{2000} \\
\hline & Faeces & Positive & Prevalence (\%) & Faeces & Positive & Prevalence (\%) & Faeces & Positive & Prevalence (\%) \\
\hline Apr. & $-^{\text {a) }}$ & - & - & 377 & 8 & 2.1 & - & - & - \\
\hline May & - & - & - & 399 & 19 & 4.8 & 410 & 41 & 10.0 \\
\hline Jun. & 400 & 22 & 5.5 & 395 & 6 & 1.5 & 404 & 37 & 9.2 \\
\hline Jul. & 396 & 45 & 11.4 & 393 & 26 & 6.6 & 388 & 29 & 7.5 \\
\hline Aug. & 395 & 91 & 23.0 & 388 & 32 & 8.2 & 394 & 0 & 0.0 \\
\hline Sep. & 393 & 21 & 5.3 & 375 & 20 & 5.3 & 395 & 10 & 2.5 \\
\hline Oct. & - & - & - & 368 & 24 & 6.5 & 163 & 2 & 1.2 \\
\hline Nov. & 118 & 5 & 4.2 & 119 & 9 & 7.6 & 132 & 5 & 3.8 \\
\hline Dec. & 88 & 6 & 6.8 & 91 & 5 & 5.5 & 96 & 3 & 3.1 \\
\hline Jan. & 79 & 11 & 13.9 & 85 & 8 & 9.4 & 91 & 2 & 2.2 \\
\hline Feb. & 82 & 8 & 9.8 & 79 & 9 & 11.4 & 92 & 2 & 2.2 \\
\hline Mar. & 75 & 5 & 6.7 & 76 & 6 & 7.9 & 92 & 5 & 5.4 \\
\hline Apr. & 78 & 8 & 10.3 & 80 & 9 & 11.3 & 87 & 17 & 19.5 \\
\hline Total & 2104 & 222 & 10.6 & 3225 & 181 & 5.6 & 2744 & 153 & 5.6 \\
\hline
\end{tabular}

a) Not tested. 


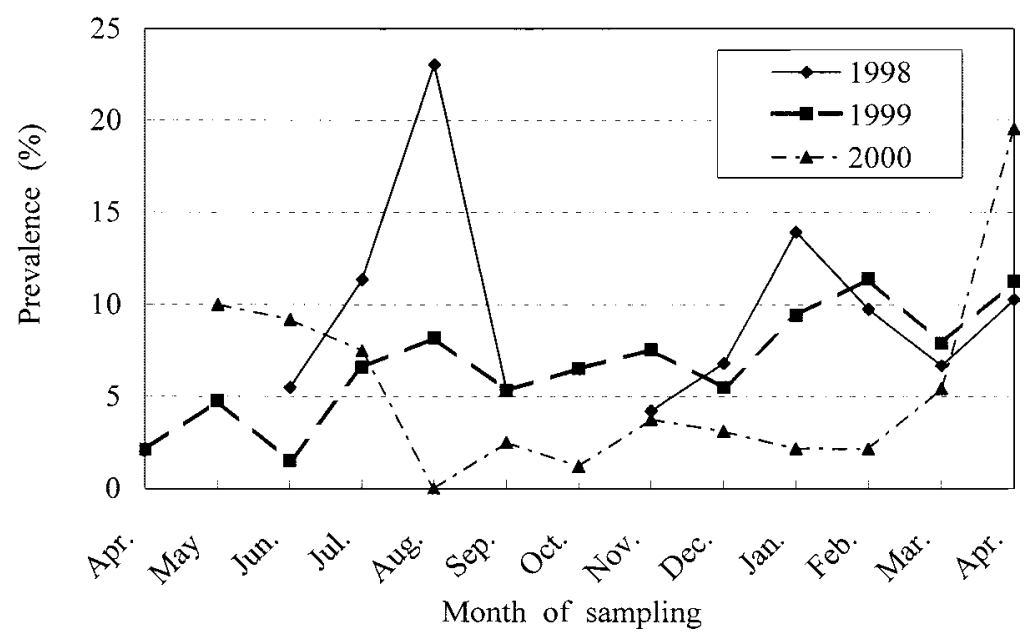

Fig. 1. Seasonal prevalence of EHEC O157 on the farm.

Table 3. Number of positive tests for EHEC O157 in the faeces from each heifer

\begin{tabular}{cccccc}
\hline \multirow{2}{*}{ Year } & \multirow{2}{*}{ Heifers } & Positive (\%) & \multicolumn{3}{c}{ No. of positive tests throughout the year } \\
\cline { 4 - 6 } & & & 1 & 2 & 3 \\
\hline 1998 & 400 & $185(46.3)$ & 153 & 27 & 5 \\
1999 & 399 & $147(36.8)$ & 118 & 24 & 5 \\
2000 & 410 & $130(31.7)$ & 107 & 23 & 0 \\
\hline Total & 1209 & $462(38.2)$ & 378 & 74 & 10 \\
\hline
\end{tabular}

in 2000, it was higher in spring than in summer and winter.

The number of times each heifer tested positive for EHEC 0157 in the faeces is shown in Table 3. Most positive heifers excreted EHEC O157 once, whereas a few tested positive 2 or 3 times.

Representive patterns of the shedding of EHEC O157 more than twice are shown in Table 4. Half of the heifers that tested positive for the organisms twice or three times throughout the year excreted the organisms twice in consecutive months, such as Nos. 23 and 371, whereas some heifers excreted them at intervals of 2 months or more, such as Nos. 52, 102 and 308. Heifer No. 102 first tested positive in June, then, after continuously testing negative for EHEC O157, the heifer excreted the organisms again the following April.

Isolation of EHEC O157 from environmental samples: EHEC O157 was isolated from 17 out of 902 (1.9\%) environmental samples (Table 5). The organisms were isolated from $6(3.6 \%)$ of 165 samples from the alley of the barn and $3(3.1 \%)$ of 96 samples of dried faeces from the paddock. The isolation rates of the other environmental samples were low.

Characteristics of EHEC O157 isolates: All isolates $(\mathrm{n}=573)$ from the faeces $(\mathrm{n}=556)$ of heifers and environmental samples $(n=17)$ were examined serological and for genetic characteristics (Table 6). Of 562 isolates belonging to the $\mathrm{O} 157: \mathrm{H} 7$ strain, 541 and 19 possessed both $s t x_{1}$ and st $x_{2}$, and 19 possessed either $s t x_{1}$ or $s t x_{2}$, respectively. Only 2 isolates possessed no stx genes. Almost all isolates belonging to the $\mathrm{O} 157: \mathrm{H}$ - strains also possessed st $x$ genes.

\section{DISCUSSION}

EHEC 0157 is a major risk factor for human health since it can cause severe diseases such as HUS and HC [9]. Since cattle are regarded as a natural reservoir of the organism, it is necessary to study the occurrence of EHEC O157 in dairy herds. In the present study, a long-term bacterial survey of EHEC O157 was performed on a farm that had shown a high prevalence rate of the organisms in previous years.

In the present study, it was observed that the prevalence of EHEC $\mathrm{O} 157$ from heifers was very high on the farm in Hokkaido. Half of the heifers examined were found positive for the organisms, though most of the EHEC O157-positive heifers excreted the organisms only once. Heuvelink and coworkers [11] reported that most cattle positive for EHEC O157 tested positive only once, and half of the cattle with two positive samples excreted the organisms on two consecutive samplings. Our results in the present study supported those of the previous report. The findings suggest that EHEC O157 is a transient organism in the bovine intestines. It is interesting that some cattle excreted the organisms long term or at intervals of several months. It is possible that the organism can persist in the intestines of cattle, or that cattle 
Table 4. Representative shedding pattern of EHEC O157 from heifers testing positive for the organisms more than twice

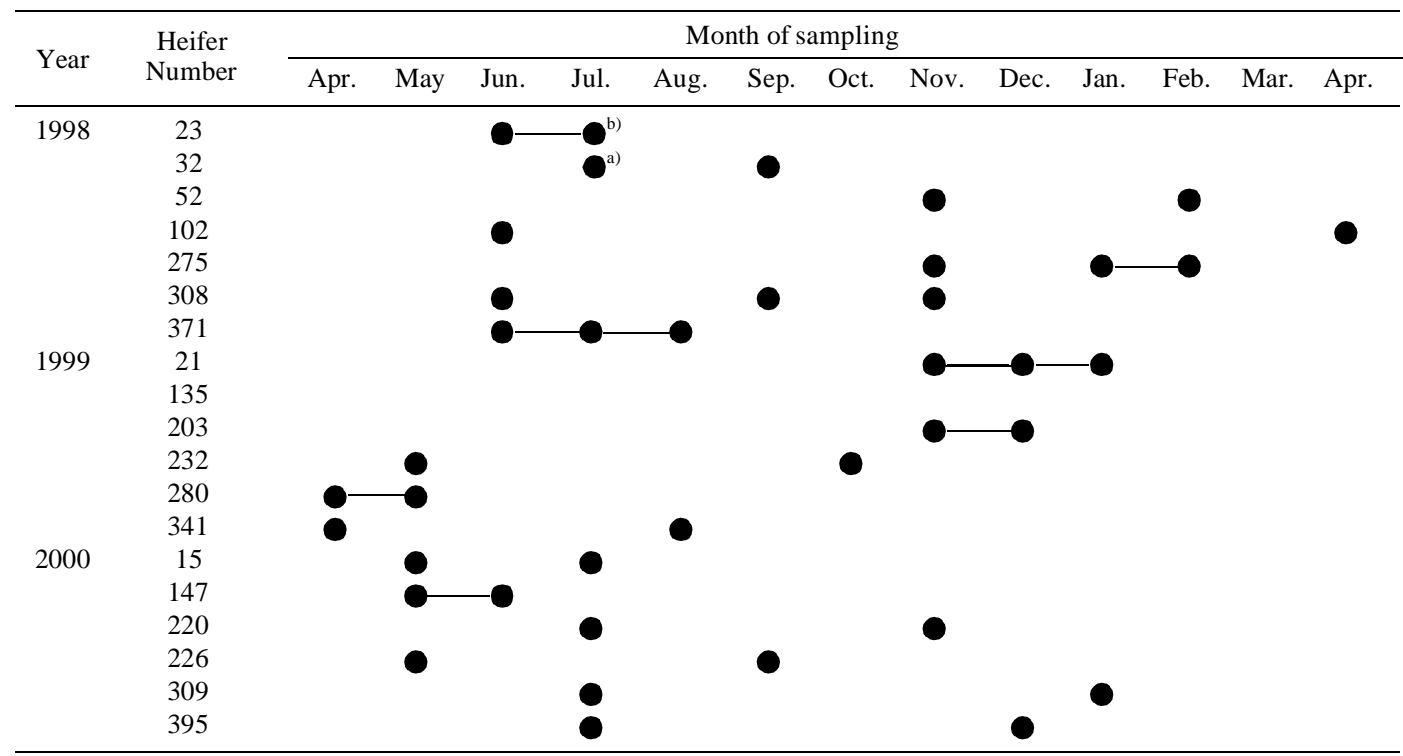

a) Positive for EHEC O157.

b) Continuously positive for EHEC O157.

Table 5. Prevalence of EHEC O157 from environmental samples

\begin{tabular}{lccc}
\hline Sample & Samples & Positive & Prevalence (\%) \\
\hline Water trough & 54 & 0 & 0 \\
Feeding trough & 176 & 2 & 1.1 \\
Mineral brock & 15 & 1 & 6.7 \\
Alley & 165 & 6 & 3.6 \\
Wall & 132 & 0 & 0 \\
Bedding & 264 & 5 & 1.9 \\
Dried faeces in paddock & 96 & 3 & 3.1 \\
\hline Total & 902 & 17 & 1.9 \\
\hline
\end{tabular}

become reinfected with different strains after clearance of EHEC O157 subsequent to the initial infection. It is necessary to make a comparison of strains by using genetic analysis methods to clarify whether these strains are identical or not.

Seasonal variations in the prevalence of EHEC O157 on the farm were also noted in the present study. The heifers reared on the farm were kept on pasture from early summer to late autumn, and were kept indoors and in paddocks from late autumn to spring. The heifers fed on grass while on pasture, whereas they were given formula feed and silage while indoors during winter. The faeces of cattle being fed grass only tended to be watery, and were widely spread over the pasture occupied by the cattle. The grasses contaminated with EHEC O157 became a new source of infection and led to an increase in the number of cattle testing positive for the organisms. Furthermore, high temperatures and humidity during summer may provide favorable conditions for the growth and survival of the organisms. Therefore, heifers on
Table 6. Genetic and serologic characteristics of EHEC O157 isolates from faeces and environment samples

\begin{tabular}{|c|c|c|c|c|c|}
\hline & st $x_{1}$ & st $x_{2}$ & $s t x_{1}$ and $s t x_{2}$ & non-stx & Total \\
\hline \multicolumn{6}{|l|}{ Faeces } \\
\hline O157:H7 & 13 & 6 & 524 & 2 & 545 \\
\hline O157:H- & 0 & 0 & 9 & 2 & 11 \\
\hline \multicolumn{6}{|l|}{ Environment } \\
\hline O157:H7 & 0 & 0 & 17 & 0 & 17 \\
\hline Total & 13 & 6 & 550 & 4 & 573 \\
\hline
\end{tabular}

the pasture became infected or reinfected with the organisms from various environmental sources. Changes in diet may also have contributed to the seasonal variations in the prevalence of EHEC 0157 [1, 17]. It is hypothesized that diets high in nutrients and low in fiber induce a lower incidence of transmission and/or shedding EHEC O157 but do not clear the organisms from the intestines. In the present study, heifers were kept indoors and in paddocks during winter. The close contact with other heifers may have resulted in the high isolation rate of EHEC O157 during winter, even though there was a lower incidence of shedding EHEC O157. Nevertheless, trends in the isolation rate of EHEC O157 varied between 1998, 1999 and 2000. Climate, such as temperature and the amount of rainfall, and breeding conditions did not differ markedly from year to year, so that the reason for the differences in bacterial isolation trends over the 3 years is not clear.

The prevalence of EHEC 0157 on the farm during the 3 years of the study (1998-2000) was $10.6 \%, 5.6 \%$ and 5.6\%, respectively. In previous reports, the prevalence of the 
organism in cattle was shown to be $0.2-60.4 \%$ in the United States [10, 13, 23, 28], 1.9\% in Australia [7], and 4.2-66.7\% in Europe [5, 6, 16, 24]. In Japan, the isolation rate of EHEC from the faeces of cattle delivered to a slaughterhouse was $0.3-6.5 \%[12,15]$. The isolation rate obtained in the present study was higher than that reported previously in Japan, and was similar to reports from the United States and Europe. The isolation rate is influenced by various factors, such as the target population, detection methods, and so on. For isolation of EHEC O157 in the present study, a large quantity $(10 \mathrm{~g})$ of bovine faeces were inoculated in an enriched broth, which might result in the high prevalence of EHEC O157. Furthermore, geographic differences may also have influenced the results. We found that the farm was highly contaminated with the organisms. The farm raised post-weaned heifers only. In a previous report, weanlings and heifers showed a higher isolation rate of EHEC O157 compared with those of calves and lactating cattle [7].

EHEC O157 was also isolated from environmental samples, though the isolation rate was low in comparison with that from faeces. Porter et al. [21] and Cobbold et al. [10] reported that EHEC O157 was more usually isolated from samples from slurry or in close proximity to the milking parlour. In this study, it was notable that EHEC O157 was detected not only in bedding and the feed trough being in direct contact with the cattle, but from the barn alley as well. As the cattle in the farm were kept out of the alley, there is a possibility that humans are a risk factor for the diffusion of EHEC O157 both inside and outside of the farm.

The results in the present study show that cattle excreted the organisms for a short period and then rid themselves of the organisms. Reiteration of infection, elimination, and new infection might maintain the prevalence of EHEC O157 on the farm. Persistent excretion might also increase the prevalence of the organisms. The results of this study showed that EHEC O157 was continuously isolated from faeces of unspecified healthy cattle over a long period and from farm environmental samples. It is thought that EHEC O157 is diffused by factors such as artificial matter and careless farming methods. Moreover, it is estimated that these factors increase the frequency of the incidence of human EHEC O157 infection. Elimination of EHEC O157 from cattle may, therefore, be important in the prevention of infection.

\section{REFERENCES}

1. Besser, T. E., Richards, B. L., Rice, D. H. and Hancock, D. D. 2001. Escherichia coli O157:H7 infection of calves: infectious dose and direct contact transmission. Epidemiol. Infect. 127: 550-560.

2. Besser, T. E., Hancock, D. D., Pritchett, L. C., McRae, E. M., Rice, D. H. and Tarr, P. I. 1997. Duration of detection of fecal excretion of Escherichia coli $\mathrm{O} 157: \mathrm{H} 7$ in cattle. J. Infect. Dis. 175: 726-729.

3. Beutin, L., Geier, D., Steinruck, H., Zimmermann, S. and Scheutz, F. 1993. Prevalence and some properties of verotoxin (Shiga-like toxin)-producing Escherichia coli in seven differ- ent species of healthy domestic animals. J. Clin. Microbiol. 31: 2483-2488.

4. Blanco, M., Blanco, J. E., Blanco, J., Gonzalez, E. A., Mora, A., Prado, C., Fernandez, L., Rio, M., Ramos, J. and Alonso, M. P. 1996. Prevalence and characteristics of Escherichia coli serotype 0157:H7 and other verotoxin-producing E. coli in healthy cattle. Epidemiol. Infect. 117: 251-257.

5. Chapman, P. A., Siddons, C. A., Cerdan Malo, A. T. and Harkin, M. A. 1997. A 1-year study of Escherichia coli $\mathrm{O} 157$ in cattle, sheep, pigs and poultry. Epidemiol. Infect. 119: 245250.

6. Cízek, A., Alexa, P., Literak, I., Hamrík, J., Novák, P. and Smola, J. 1999. Shiga toxin-producing Escherichia coli O157 in feedlot cattle and Norwegian rats from a large-scale farm. Lett. Appl. Microbiol. 28: 435-439.

7. Cobbold, R. and Desmarchelier, P. 2000. A longitudinal study of Shiga-toxigenic Escherichia coli (STEC) prevalence in three Australian dairy herds. Vet. Microbiol. 71: 125-137.

8. Ezawa, A., Gocho, F., Kawata, K., Takahashi, T. and Kikuchi, N. 2004. High prevalence of enterohemorrhagic Escherichia coli (EHEC) 0157 from cattle in selected regions of Japan. $J$. Vet. Med. Sci. 66: 585-587.

9. Geue, L., Segura-Alvarez, M., Conraths, F. J., Kuczius, T., Bockemühl, J., Karch, H. and Gallien, P. 2002. A long-term study on the prevalence of shiga toxin-producing Escherichia coli (STEC) on four German cattle farms. Epidemiol. Infect. 129: 173-185.

10. Hancock, D. D., Besser, T. E., Rice, D. H., Herriott, D. E. and Tarr, P. I. 1997. A longitudinal study of Escherichia coli O157 in fourteen cattle herds. Epidemiol. Infect. 118: 193-195.

11. Heuvelink, A. E., van den Biggelaar, F. L. A. M., de Boer, E., Herbes, R. G., Melchers, W. J. G., Huis in't veld, J. H. J. and Monnens, L. A. H. 1998. Isolation and characterization of verocytotoxin-producing Escherichia coli 0157 strains from Dutch cattle and sheep. J. Clin. Microbiol. 36: 878-882.

12. Kanda, T., Shiozawa, K., Sato, F., Aoki, K. and Nishina, T. 1992. Isolation of Escherichia coli $\mathrm{O} 157: \mathrm{H} 7$ from faces of cattle in Japan. J. Jpn. Vet. Med. Assoc. 45: 45-47 (in Japanese).

13. Keen, J. E. and Elder, R. O. 2002. Isolation of shiga-toxigenic Escherichia coli $\mathrm{O} 157$ from hide surfaces and the oral cavity of finished beef feedlot cattle. J. Am. Vet. Med. Assoc. 220: 756763.

14. Kobayashi, H., Shimada, J., Nakazawa, M., Morozumi, T., Pohjanvirta, T., Pelkonen, S. and Yamamoto, K. 2001. Prevalence and characteristics of shiga toxin-producing Escherichia coli from healthy cattle in Japan. Appl. Environ. Microbiol. 67: 484-489.

15. Kushima, S., Maehara, T., Kubo, M., Hoshino, T., Gotoh, K., Omoe, K. and Shinagawa, K. 2001. Prevalence of Enterohemorrhagic Escherichia coli in cattle by two different selective enrichment culture methods. J. Jpn. Vet. Med. Assoc. 54: 391394 (in Japanese).

16. Lahti, E., Eklund, M., Ruutu, P., Siitonen, A., Rantala, L., Nuorti, P. and Honkanen-Buzalski, T. 2002. Use of phenotyping and genotyping to verify transmission of Escherichia coli O157:H7 from dairy farms. Eur. J. Clin. Microbiol. Infect. Dis. 21: 189-195.

17. Mechie, S. C., Chapman, P. A. and Siddons, C. A. 1997. A fifteen month study of Escherichia coli O157:H7 in dairy herd. Epidemiol. Infect. 118: 17-25.

18. Miyao, Y., Kataoka, T., Nomoto, T., Kai, A., Itoh, T. and Itoh, K. 1998. Prevalence of verotoxin-producing Escherichia coli harbored in the intestine of cattle in Japan. Vet. Microbiol. 61: 
137-143.

19. Murinda, S. E., Nguyen, L. T., Ivey, S. J., Gillespie, B. E., Almeida, R. A., Draughon, F. A. and Oliver, S. P. 2002. Prevalence and molecular characterization of Escherichia coli O157:H7 in bulk tank milk and fecal samples from cull cows: a 12-month survey of dairy farms in East Tennessee. J. Food Prot. 65: 752-759.

20. Ohmura, M., Yamasaki, S. and Takeda., Y. 1996. Identification of enterohemorrhagic Escherichia coli by polymerase chain reaction. Clin. Microbiol. 23: 813-819 (in Japanese).

21. Porter, J., Mobbs, K., Hart, C. A., Saunders, J. R., Pickup, R. W. and Edwards, C. 1997. Detection, distribution and probable fate of Escherichia coli $\mathrm{O} 157$ from asymptomatic cattle on dairy a farm. J. Appl. Microbiol. 83: 297-306.

22. Rahn, K., Renwick, S. A., Johnson, R. P., Wilson, J. B., Clarke, R. C., Alves, D., McEwen, S., Lior, H. and Spika, J. 1997. Persistence of Escherichia coli $\mathrm{O} 157: \mathrm{H} 7$ in dairy cattle and the dairy farm environment. Epidemiol. Infect. 119: 251-259.

23. Sargeant, J. M., Gillespie, J. R., Oberst, R. D., Phebus, R. K., Hyatt, D. R., Bohra, L. K. and Galland, J. C. 2000. Results of a longitudinal study of the prevalence of Escherichia coli O157:H7 on cow-calf farms. Am. J. Vet. Res. 61: 1375-1379.
24. Tutenel, A. V., Pierard, D., Uradzinski, J., Jozwik, E., Pastuszczak, M., Van Hende, J., Uyttendaele, M., Debevere, J., Cheasty, T., Van Hoof, J. and De Zutter, L. 2002. Isolation and characterization of enterohaemorrhagic Escherichia coli O157:H7 from cattle in Belgium and Poland. Epidemiol. Infect. 129: $41-47$.

25. Wells, J. G., Shipman, L. D., Greene, K. D., Sowers, E. G., Green, J. H., Cameron, D. N., Downes, F. P., Martin, M. L., Griffin, P. M., Ostroff, S. M., Potter, M. E., Tauxe, R. V. and Wachsmuth, I. K. 1991. Isolation of Escherichia coli serotype O157:H7 and other Shiga-like-toxin-producing E. coli from dairy cattle. J. Clin. Microbiol. 29: 985-989.

26. Woody, J-M., Walsh, R. A., Doores, S., Henning, W. R., Wilson, R. A. and Knabel, S. J. 2000. Role of bacterial association and penetration on destruction of Escherichia coli $\mathrm{O} 157: \mathrm{H} 7$ in beef tissue by high pH. J. Food. Prot. 63: 3-11.

27. Yilmaz, A., Gun, H. and Yilmaz, H. 2002. Frequency of Escherichia coli $\mathrm{O} 157: \mathrm{H} 7$ in Turkish cattle. J. Food Prot. 65: 1637-1640.

28. Zhao, T., Doyle, M. P., Shere, J. and Garber, L. 1995. Prevalence of enterohemorrhagic Escherichia coli $\mathrm{O} 157: \mathrm{H} 7$ in a survey of dairy herds. Appl. Environ. Microbiol. 61: 1290-1293. 